\title{
National Development Emphasizing on the Manufacturing Industry Sector in West Java Province
}

\author{
Narsih $^{1}$, Cicih Ratnasih ${ }^{2}$, Pudji Astuty ${ }^{3}$ \\ \{narsihpurnomo72@gmail.com ${ }^{1}$, Cicih_ratnasih@borobudur.ac.id ${ }^{2}$, puji_astuty@borobudur.ac.id ${ }^{3}$ \} \\ Universitas Borobudur, Jakarta, Indonesia ${ }^{1,2,3}$
}

\begin{abstract}
Implementation of development is certainly not far from the economic and social conditions of a nation or state. The success of economic growth is seen from the management factor carried out by the workforce. In this case, labor is a critical element in national development. This study takes a sample in the Government of West Java Province where operational variables are needed to analyze the problem. Descriptive and verification methods are used to explain each of the variables intended in this study, such as the number of manufacturing companies, the number of manufacturing production, and the human development index, which are aligned with the efforts of the West Java Provincial government to conduct job pieces of training, collect data on the working-age community, and continue to do so. They are seeking to attract investment in the industrial sector.
\end{abstract}

Keywords: National Development; Manufacturing; Industry

\section{Introduction}

The direction of Indonesia's development is carried out in the context of the welfare of its people by creating a just, prosperous, equitable society both materially and spiritually based on Pancasila and the 1945 Constitution of the Republic of Indonesia [1]. The primary and fundamental problem is low wages and high unemployment rates, and population growth that continues to increase. In this case, the increase in new workers is more significant than the growth in employment provided every year, which is one of the primary reasons for the emergence of the natural rate of unemployment that occurs in every country [2].

In Indonesia, one of the causes of many unemployed people is many working-age or productive age who do not have or do not have a job [3]. This condition is felt by Indonesia, where national development, which requires human resources, is a severe problem. Not only at this point, but since 1997 when Indonesia was experiencing an economic and political crisis, the world of employment has also been badly affected [4]. The similarities between the economic and political crises in the past are re-identified in the present. The only thing that makes the difference is the causative factor, namely the Covid-19 pandemic that has hit all countries worldwide [5]. Bank Indonesia projects that there will be an $11.25 \%$ increase in the poverty rate to 30.3 million people this year and will impact the transportation, trade, hotels and restaurants, construction, processing, and agriculture sectors. 


\section{Methodology}

This research was conducted in West Java Province, covering all districts/cities in West Java Province. Using descriptive and verification methods, the research time will be six months, from November 2020 to April 2021. This study will describe each variable and explain the influence between the variables studied. At the same time, the type of influence between the variables used in the study is causality, which is the independent variable affecting the dependent variable. Verificative research refers to the formulation of research problems and hypotheses to be tested against the phenomena. This research begins with a preliminary study, both literature and field studies, on the object under investigation. This study is further elaborated on the background of the problem, which is then defined as problem identification, problem definition, and problem formulation. The next stage is the framework of thinking and research hypotheses set by operational variables. Next, collect primary data as a basis for regression analysis, data testing, and hypothesis testing. If the data test meets the applicable statistical testing criteria, further investigation is carried out by testing the hypothesis. From the data analysis and hypothesis testing, conclusions and suggestions were determined so that the formulation of the research problem was answered.

\section{Results and Discussion}

\subsection{Economic Development Concept}

Economic growth is one indicator of the success of development in an economy. In general, the theory of economic growth can be grouped into two, namely the classical economic growth theory initiated by economists, including Adam Smith and David Ricardo, which is an analysis based on the belief and effectiveness of the free market mechanism, and modern economic theory emphasizes the importance of investment formation. For economic growth. The higher the investment, the better the economy. In a longer perspective, the investment will increase the capital stock [6].

The concept of labor has several definitions, namely based on Law no. 25 of 1997, and the workforce is every man or woman. He will do work, both inside and outside the employment relationship, to produce goods or services to meet the community's needs. Meanwhile, according to Simanjuntak [7], residents aged 10 years or more are already or are working, looking for work, and carrying out other activities such as school and taking care of the household. Supply and demand for labor in economic development is a factor that affects employment. Absorbed labor is a demand model of a business unit (company agency) on the labor market that can be affected by an increase in the production process. The demand for labor is related to the number of workers required by a particular agency or company (influenced by wage levels and other changes that affect the demand for output). At the same time, the explanation of the labor supply is the amount of labor provided by the workforce owner at every possible wage and type of work within a specific time [8].

According to Putra [9], several factors affect economic growth in general, including:

a. Natural resources

b. Number and quality of population education

c. Science and technology

d. Social system

e. Market 
The five factors mentioned above show that the role of humans/society as workers is critical because humans are the controllers in creating national development. Thus, human development programs are needed as the central controller and capital in national growth, namely by fulfilling the classification of skills, knowledge, and competencies in various fields of expertise. Development is calculated using the number of education, health, and purchasing power or empowering the population to achieve optimal economic growth. The industry has the meaning of activities produced in converting raw materials into homogeneous goods or goods that have interchangeable properties very closely, or in another sense are economic activities that deliver added value in an item. In contrast, the manufacturing industry in the economic realm has its meaning: a collection of firms that produce the same or very similar goods in a market.

\subsection{Manufacturing Industry Development in Indonesia and West Java}

The development of the manufacturing industry in Indonesia is considered more productive. It can have a broad chain effect to increase the added value of raw materials, increase the workforce, generate the largest source of foreign exchange, and be the most significant contributor to taxes and customs duties (Minister of Industry, 2020). Several Indonesian manufacturing sectors are also being developed in other ASEAN countries such as the Philippines and Vietnam. This kind of thing, of course, will encourage economic growth nationally and increase competitiveness domestically, regionally, and globally as it is known that the Manufacturing Value Added (MVA) value for the Indonesian manufacturing industry is in the top position among ASEAN countries with an achievement of $4.5 \%$. Apart from being developed in neighboring countries, the manufacturing industry in Indonesia is the largest in ASEAN because the economic system in Indonesia is included in the Oe Trillion Dollar Club group, which is different from other countries in ASEAN.

Before the Covid-19 pandemic occurred, the processing industry in the country still showed positive passion. This is reflected in the achievement of the Purchasing Managers' Index (PMI) of Indonesian manufacturing released by HIS Markit in February 2020 at 51.9, or the highest since 2005. The Ministry of Industry (Kemenperin) recorded the investment value of the manufacturing industry during the first quarter of the year. 2020 reached Rp 64 trillion, up $44.7 \%$ compared to the previous year's achievement in the same period of Rp 44.2 trillion. This achievement shows a positive number during the pressure due to the Covid-19 pandemic.

West Java is the province with the highest investment value in Indonesia. Throughout 2019, investment from abroad that came to province ii (West Java) was recorded at Rp 137 trillion. Investors choose West Java as the location to invest because of the skilled workforce and higher labor productivity and labor productivity. Following the West Java Governor's statement saying that in 2020, tourism and manufacturing will be the driving force for investment in West Java. This effort is carried out by continuously creating a conducive business climate, expanding the export market for industrial manufacturing, and encouraging creative industries. In addition, efforts to promote investment and strengthen people's purchasing power need to be continued. 


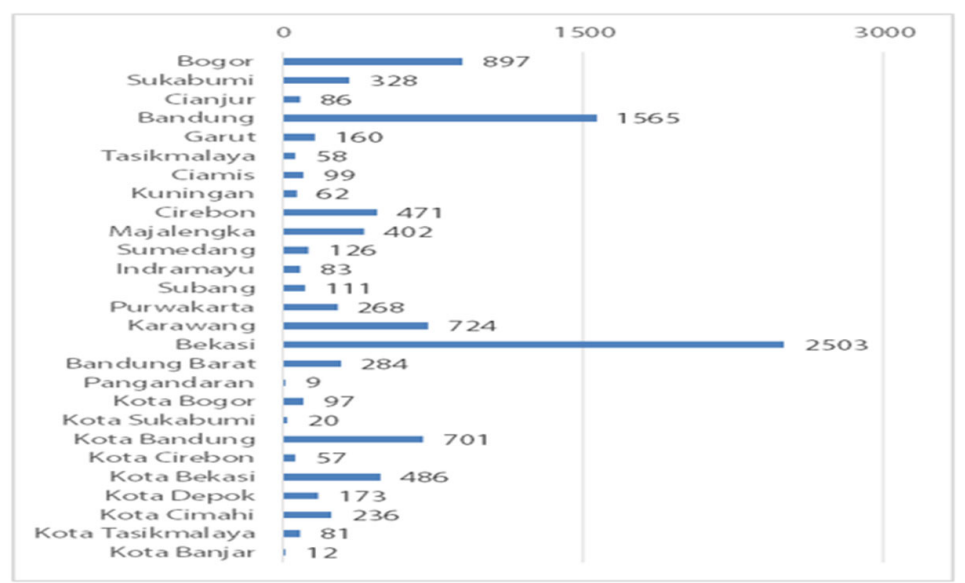

Fig. 1. Number of Companies in Large and Medium Industries by Regency/City, 2017

The variable number of manufacturing industry companies is proxied by the number of companies in the manufacturing sector industry in West Java Province in a certain period with units. The following table describes the mean, standard deviation, minimum value, and maximum value of the Number of Manufacturing Industry Companies:

Table 1. Descriptive Variable Number of Manufacturing Industry Companies

\begin{tabular}{lc}
\hline & Number of Companies Industri Manufaktur (Unit) \\
\hline Mean & $6.704,20$ \\
Standar Deviasi & $1.160,95$ \\
Min & $4.536,00$ \\
Max & $10.099,00$ \\
\hline
\end{tabular}

Based on the table above, the average value of the Number of Manufacturing Industry Companies in West Java Province is 6,704.20 companies with a standard deviation of 1,160.95. The lowest number of manufacturing industrial companies in West Java Province was 408,260 companies in 2005Q1, and the highest number of Manufacturing Industry Companies in West Java Province was 10,099 in 2019Q2. Variable Amount of Manufacturing Industry Production is proxied by the amount of production in the manufacturing sector industry in West Java Province in a certain period with Units. The following table describes the mean, standard deviation, minimum value, and maximum value of the Total Manufacturing Industry Production:

Table 2. Descriptive Variable Number of Manufacturing Industry Production

\begin{tabular}{lc}
\hline & Total Manufacturing Industry Production (Billion Rp) \\
\hline Mean & $950.332,50$ \\
Standar Deviasi & $637.218,89$ \\
Min & $274.364,00$ \\
MAx & $2.314 .863,00$ \\
\hline
\end{tabular}

Based on the table above, the average value of the Total Manufacturing Industry Production in West Java Province is Rp. 950,332.50 billion with a standard deviation of Rp. 
637,218.89 billion. The lowest Total Manufacturing Industry Production in West Java Province was IDR 274,364.00 billion in 2005Q1, and the highest Total Manufacturing Industry Production in West Java Province was IDR 2,314,863.00 billion in 2019Q1. The Human Development Index variable is proxied by the Human Development Index in West Java Province in a certain period with units. The following table describes the mean, standard deviation, minimum value, and maximum value of the Regional Economic Growth Rate:

Table 3. Descriptive Variable Number of the Regional Economic Growth Rate

\begin{tabular}{lc}
\hline & Human Development Index (Unit) \\
\hline Mean & 69,46 \\
Standar Deviasi & 1,76 \\
Min & 66,15 \\
Max & 72,03 \\
\hline
\end{tabular}

Based on the table above, the average value of the Human Development Index in West Java Province is 69.46, with a standard deviation of 1.76. The lowest Human Development Index in West Java Province was 66.15 in 2010Q2, and the highest was 72.03 in 2019Q2. In line with the significant potential contribution of the manufacturing industry sector to employment for the Indonesian government in general, especially for the West Java regional government and the business world in West Java Province, the Central Government through the relevant ministries, must prioritize various aspects of supporting the improvement of the quality of work, considering that most industries manufacturing is in the province of West Java. In addition, the central and regional governments issue various regulatory incentives that encourage increased employment by conducting training for job seekers, collecting data for job seekers and unemployed, and continuing to seek investment in the manufacturing industry sector in particular and other sectors in general.

\section{Conclusion}

National economic growth prioritizes the progress of human/society development to control and strive for national development. The influence that can increase national economic growth is from manufacturing companies that run an investment system. Many of these manufacturing companies are found in the West Java region. From data taken from research in West Java, three main elements are drawn: the number of manufacturing companies, the number of manufacturing production, and the human development index. From these data, it can be concluded that the central and regional governments, especially the Province of West Java, to advance the manufacturing sector that impacts national development require a significant absorption of labor by paying attention to the management of the people themselves.

\section{References}

[1] E. E. Supriyanto, "PENERAPAN NILAI-NILAI PANCASILA DALAM KEBIJAKAN EKONOMI DI KABUPATEN TEGAL 2009-2014 Eko Eddya Supriyanto,” J. Polit., vol. 2, no. 1, 2016.

[2] M. Ssenyonga, "Imperatives for post COVID-19 recovery of Indonesia's education, labor, and SME sectors," Cogent Econ. Financ., vol. 9, no. 1, 2021, doi: 
10.1080/23322039.2021.1911439.

[3] S. Hail, Economics for Sustainable Prosperity. 2018.

[4] T. I. Palley, "Money, Fiscal Policy, and Interest rates: A Critique of Modern Monetary Theory," 2013.

[5] S. Magiera, "Indonesia's investment negative list:An evaluation for selected services sectors," Bull. Indones. Econ. Stud., vol. 47, no. 2, pp. 195-219, 2011, doi: 10.1080/00074918.2011.585947.

[6] M. Wickens, Macroeconomic Theory A Dynamic General Equilibrium Approach, vol. 1, no. 9. 2008.

[7] T. H. Simanjuntak and I. Mukhlis, "Empirical Study about The Interaction Between Equalization Funds, Regional Financial and Human Development Index in Regional Economic," Int. J. Econ. Financ., vol. 7, no. 1, pp. 192-202, 2014, doi: 10.5539/ijef.v7n1p192.

[8] K. Ishikawa, "The ASEAN Economic Community and ASEAN economic integration," J. Contemp. East Asia Stud., vol. 10, no. 1, pp. 24-41, 2021, doi: 10.1080/24761028.2021.1891702.

[9] A. S. Putra, G. Tong, and D. O. Pribadi, "Spatial analysis of socio-economic driving factors of food expenditure variation between provinces in Indonesia," Sustain., vol. 12, no. 4, pp. 1-18, 2020, doi: 10.3390/su12041638. 